\title{
EXTRACTION-SPECTROPHOTOMETRIC DETERMINATION OF NICKEL AT MICROGRAM LEVEL IN WATER AND WASTEWATER USING 2-[(2-MERCAPTOPHENYLIMINO)METHYL]PHENOL
}

\author{
A.M. Haji Shabani, S. Dadfarnia ${ }^{*}$ Z. Shahbaazi and A.A. Jafari \\ Department of Chemistry, Yazd University, Yazd 89195-741, Iran
}

(Received December 26, 2007; revised June 17, 2008)

\begin{abstract}
An extraction-spectrophotometric method for determination of nickel at sub ppm level using 2[(2-mercaptophenylimino)methyl]phenol (MPMP) as the new extractant is described. The reagent reacts with nickel(II) at $\mathrm{pH}>10$ and form a 1:2 brown complex, which is extracted into chloroform. The complex has a maximum absorption at $421 \mathrm{~nm}$ with the molar absorptivity of $2.41 \times 10^{5} \mathrm{M}^{-1} \mathrm{~cm}^{-1}$. Beer's law is obeyed over the range of $0.011-0.30 \mu \mathrm{g} \mathrm{mL} \mathrm{m}^{-1}$. The Sandell's sensitivity for 0.001 absorbance unit is $5.34 \times 10^{-4} \mu \mathrm{g} \mathrm{cm}^{-2}$. The relative standard deviation at $0.018 \mu \mathrm{g} \mathrm{mL}^{-1}$ is $1.1 \%(\mathrm{n}=8)$. The procedure was successfully applied to determination of nickel in wastewater and standard alloy and the accuracy was determined by recovery experiment, independent analysis by furnace-AAS, and analysis of a certified reference martial.
\end{abstract}

KEY WORDS: Ni determination, Liquid-liquid extraction, Schiff bases, Spectrophotometry

\section{INTRODUCTION}

Nickel is widely used in electroplating, the manufacture of $\mathrm{Ni}-\mathrm{Cd}$ batteries, rods for arc welding, pigments of paints, ceramic, surgical and dental prostheses, magnetic tapes and computer components and nickel catalysts. Nickel enters waters from dissolution of industrial processes and waste disposal [1]. Nickel was thought to be essential for plants and some domestic animals [2], but not considered to be a metal of biological importance until 1975, when Zerner discovered that urease was a nickel enzyme [3]. Nickel is essential constituent in plant urease. Jack beans and soybeans generally contain high concentration of nickel [1]. Compared with other transition metals, nickel is moderately toxic element, and still at low concentration produces a general toxic effect on the human organism, causing nasopharynx and lung diseases, malignant tumors and dermatological discase [4]. Nickel-containing sewage is harmful after ingress into water. This fact explained the importance of the monitoring of nickel concentration in natural and waste water samples. Flame and graphite furnace atomic absorption spectrometry and spectrophotometric methods provides accurate and rapid determination of nickel in natural and waste waters [5]. However, very frequently a direct determination can not be applied due to low concentration of analyte or matrix interferences.

The most widely used techniques for the separation and preconcentration of nickel are liquid-liquid extraction [6], precipitation [7], and chelating resin [8]. The large distribution ratios attainable in some solvent extraction systems allow the analytes determination at trace levels.

An advantage of solvent extraction is that both separation and preconcentration which are often required; can be obtained in the same step [9]. Historically the first instance of chemical analysis of metal ions was combination of liquid extraction and spectrophotometric methods, in which the analysis was performed on the extracting phase. Nevertheless, the solvent extraction of nickel is still an important process and is used in several plants to recover and separate nickel from wastewaters $[10,11]$. Many classical ligands such as dimethylglyoxime, dithizone, and sodium-diethyldithiocarbamate are known as an extractant for extraction/spectrophotometric determination of nickel $[12,13]$.

*Corresponding author. E-mail: sdadfarnia@yazduni.ac.ir 
In this work the capability of 2-[(2-mercaptophenylimino)methyl]phenol (MPMP, Figure 1) for the extraction and spectrophotometric determination of nickel is investigated. MPMP is a tridentate Schiff base, derived from salicylaldehyde (salen). Schiff bases are known to form stable complexes with metal ions $[14,15]$. There are some reports dealing with the analytical application of this type of ligands as ion carrier in construction of membrane electrode [16], and modifier in solid phase extraction $[17,18]$; we also recently find that octadecyl silica membrane disk modified by MPMP has the capability of retention of silver from aqueous sample [19]. However, the use of Schiff bases as extractant in liquid extraction is rare [20, 21]. So it was appropriate to consider the capability of Schiff base for the separation and preconcentration of metal ions by liquid-liquid extraction. Studies confirmed the reliability of MPMP as an extractant of $\mathrm{Ni}$ and a rapid, sensitive and efficient extraction/spectrophotometric method for determination of nickel at trace level in water and wastewater samples was developed.

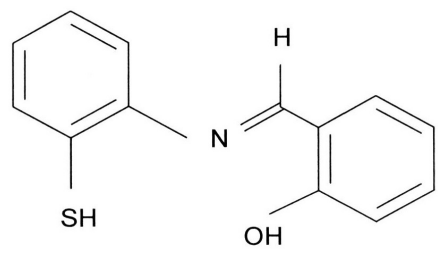

Figure 1. Structure of the Schiff base MPMP.

\section{EXPERIMENTAL}

Reagents

All reagents and solvents were of analytical reagent grade. 2-[(2-Mercaptophenylimino)methyl]phenol was synthesized and purified as described else where [22, 23]. Doublydistilled deionized water was used throughout this work. Methanol and chloroform (both from Merck, Germany) were of extra pure grade and were used as received. The stock solution of nickel $\left(1 \times 10^{-2} \mathrm{M}\right)$ was prepared by dissolving an appropriate amount of $\mathrm{Ni}\left(\mathrm{NO}_{3}\right)_{2} \cdot 6 \mathrm{H}_{2} \mathrm{O}$ in 1 $\mathrm{mL}$ of nitric acid in a $100 \mathrm{~mL}$ volumetric flask, and diluted to the mark with water. Standard solutions of nickel were prepared by appropriate dilution of stock solution. The ammonium buffer ( $\mathrm{pH} \sim 10.5 \pm 0.5$ ) was prepared by dissolving $6.75 \mathrm{~g}$ of ammonium chloride in $500 \mathrm{~mL}$ of doubly distilled water, adding $57 \mathrm{~mL}$ of concentrated ammonia and diluting to one litter with water.

Apparatus

A Jenway Model 6300 UV-Visible spectrophotometer (England) with a $1 \mathrm{~cm}$ optical path tubular glass cell was used for all absorbance measurements. The UV-Visible spectra were recorded with a JASCO Model 7800 double-beam spectrophotometer (Japan) with a $1 \mathrm{~cm}$ quartz cell. For measurement of nickel in the aqueous phase, a Buck scientific atomic absorption spectrometer (model 210, VGP, USA) equipped with a nickel hallow cathode lamp was used. $\mathrm{pH}$ values were determined with a Metrohm model $694 \mathrm{pH}$ meter (Swiss) equipped with a combined glass-calomel electrode. 


\section{Procedure}

To an aliquot of a solution containing not more than $30 \mu \mathrm{g}$ of nickel $10 \mathrm{~mL}$ of ammonium buffer ( $\mathrm{pH} \approx 10.5$ ) was added and was dilute to $100 \mathrm{~mL}$. The solution was transferred into a 150 $\mathrm{mL}$ separatory funnel. The mixture was extracted with $5 \mathrm{~mL}$ of $1 \times 10^{-3} \mathrm{M}$ of MPMP in chloroform by shaking the funnel vigorously for $10 \mathrm{~min}$, allowed the phases to separate and the absorbance of the organic phase was measured at $421 \mathrm{~nm}$ against a reagent blank.

\section{RESULTS AND DISCUSSION}

In the preliminary study it was confirmed that 2-[(2-mercaptophenylimino)methyl]phenol form a chloroform extractable complex with nickel. MPMP has one nitrogen, one oxygen and one sulfur donating group in its structure and is soluble in organic solvent but not in water at neutral $\mathrm{pH}$. Therefore it can act as tridentate ligand and from a neutral metal chelate with nickel(II), which extracts into non-polar solvents such as chloroform. The absorption spectra of the complex of nickel with MPMP showed a maximum at $421 \mathrm{~nm}$ with a molar absorptivity of $2.4 \mathrm{x}$ $10^{5} \mathrm{M}^{-1} \mathrm{~cm}^{-1}$, whereas the ligand has a negligible absorbance at this wavelength. Thus $421 \mathrm{~nm}$ was selected for the absorbance measurements.

\section{Effect of $p H$}

The extraction of nickel with MPMP was carried out over the pH range of 2-12. It was found that the extraction efficiency is highly dependent on sample $\mathrm{pH}$ and quantitative extraction was achieved at $\mathrm{pH}$ greater than 10. The extraction of nickel from aqueous phase decrease progressively at lower $\mathrm{pH}$. This is probably due to protonation of the ligand which cause a decrease in the stability of its complex with $\mathrm{Ni}^{2+}$ ions. Although nickel may precipitate in aqueous phase at high $\mathrm{pH}$, but it will dissolve in the presence of MPMP complexing agent, and in this experiment no precipitate was observed.

\section{Effect of MPMP concentration}

It was found that at a MPMP concentration of greater than $8 \times 10^{-4} \mathrm{M}$, maximum extraction is achieved and level off at higher concentration of ligand. Thus, an optimum concentration of $1 \mathrm{x}$ $10^{-3} \mathrm{M}$ of MPMP in chloroform was selected for the study.

\section{Effect of shaking time}

The extraction of nickel under the concentration recommended in the procedure is rapid. Varying the shaking period from 2 to $14 \mathrm{~min}$ showed that 6 min shaking is sufficient for quantitative extraction of nickel. Thus the kinetic of complex formation and extraction of nickel and MPMP is fast.

\section{Composition of the extraction species}

The stoichiometry of the complex of Ni(II)-MPMP was confirmed by performing spectrophotometric measurements using Job and slope ratio method [24].

In Job's method the amount of nickel in aqueous phase and MPMP in the organic phase were varied so that their sum was equal to $1 \times 10^{-4} \mathrm{mmol}$. The $\mathrm{pH}$ was kept constant at 10.5 by 
ammonium buffer solution. The maximum absorbance value corresponds to a mole ratio $\left[\mathrm{Ni}^{2+}\right] /$ [MPMP] of 1:2 which supports a $\mathrm{NiL}_{2}$ stoichiometry.

In the slope ratio method two series of experiments were performed. In the first series the concentration of the ligand in the organic phase was kept constant $\left(1 \times 10^{-4} \mathrm{M}\right)$ while the concentration of nickel in aqueous phase was varied from $1 \times 10^{-5}-8 \times 10^{-5} \mathrm{M}$. In the second series the concentration of nickel in aqueous phase was kept constant at $1 \times 10^{-4} \mathrm{M}$ while [MPMP] was varied $\left(1 \times 10^{-5}-8 \times 10^{-5} \mathrm{M}\right)$. Two straight lines, with a slope ratio of $2: 1$ were obtained, which suggest again that the complex has the formula of $\mathrm{NiL}_{2}$.

\section{Analytical performance}

In order to quantify nickel at low level ( $\mu \mathrm{g}$ level) the preconcentration capability of the extraction system was investigated by extracting $17 \mu \mathrm{g}$ of nickel from different volume of water $(5-150 \mathrm{~mL})$ according to the recommended procedure. The results showed that up to $130 \mathrm{~mL}$, the extraction was quantitative. Thus based on the consideration of the ratio of aqueous phase $(130 \mathrm{~mL})$ to the organic phase $(5 \mathrm{~mL})$, a preconcentration factor of 26 was obtained for the method.

Performance characteristic of the developed technique was obtained by extracting standard solution of nickel. For an aqueous volume of $100 \mathrm{~mL}$ the calibration graph exhibited linearity over the range of $0.01-0.30 \mu \mathrm{g} \mathrm{mL}^{-1}$ with a correlation coefficient of $0.9998(\mathrm{~A}=4.1225 \mathrm{C}$ 0.0012 where $\mathrm{A}$ is the absorbance and $\mathrm{C}$ is concentration of nickel in $\mu \mathrm{g} \mathrm{mL}^{-1}$ ). The Sandell's sensitivity [25] for 0.001 absorbance was $5.34 \times 10^{-4} \mu \mathrm{g} \mathrm{cm}^{-2}$. The relative standard deviation (95\% confidence level) for $0.17 \mu \mathrm{g} \mathrm{mL}^{-1}$ of nickel was found to be $1.1 \%(\mathrm{n}=8)$.

Table 1. Effect of foreign ions in determination of nickel $\left(3 \times 10^{-4} \mathrm{mmol}\right)$ from $100 \mathrm{~mL}$ of aqueous samples.

\begin{tabular}{|c|c|c|}
\hline Foreign ion & Mole ratio $\left[\mathrm{M}^{\mathrm{n}+} / \mathrm{Ni}^{2+}\right]$ & Recovery $(\%)$ \\
\hline $\mathrm{Ag}^{+}$ & 400 & $99.2 \pm 0.5$ \\
$\mathrm{CO}_{3}{ }^{2-}$ & 400 & $97.2 \pm 0.4$ \\
$\mathrm{Sr}^{2+}$ & 300 & $98.8 \pm 0.5$ \\
$\mathrm{Zn}^{2+}$ & 300 & $97.6 \pm 0.3$ \\
$\mathrm{Na}^{+}$ & 300 & $98.9 \pm 0.2$ \\
$\mathrm{~K}^{+}$ & 300 & $97.3 \pm 0.4$ \\
$\mathrm{Cs}^{+}$ & 300 & $96.9 \pm 0.6$ \\
$\mathrm{SO}_{4}{ }^{2-}$ & 300 & $95.5 \pm 0.5$ \\
$\mathrm{NO}_{3}{ }^{3}$ & 300 & $96.9 \pm 0.4$ \\
$\mathrm{PO}^{3}$ & 300 & $95.2 \pm 0.2$ \\
$\mathrm{Mg}^{2+}$ & 250 & $98.2 \pm 0.3$ \\
$\mathrm{Ca}^{2+}$ & 250 & $98.4 \pm 0.5$ \\
$\mathrm{Al}^{3+}$ & 250 & $97.1 \pm 0.4$ \\
$\mathrm{CH}_{3} \mathrm{COO}^{-}$ & 250 & $96.4 \pm 0.6$ \\
$\mathrm{Mn}^{2+}$ & 200 & $97.7 \pm 0.2$ \\
$\mathrm{I}^{-}$ & 200 & $95.2 \pm 0.3$ \\
$\mathrm{Br}^{-}$ & 200 & $96.6 \pm 0.4$ \\
$\mathrm{~Pb}^{2+}$ & 50 & $98.6 \pm 0.5$ \\
$\mathrm{Cd}^{2+}$ & 50 & $95.5 \pm 0.6$ \\
$\mathrm{Cu}^{2+}$ & 20 & $97.1 \pm 0.4$ \\
$\mathrm{Co}^{2+}$ & 20 & $95.6 \pm 0.3$ \\
$\mathrm{Pt}^{2+}$ & 20 & $96.2 \pm 0.2$ \\
$\mathrm{Fe}^{2+}$ & 20 & $95.3 \pm 0.5$ \\
$\mathrm{Hg}^{2+}$ & 20 & $95.8 \pm 0.4$ \\
$\mathrm{Cr}^{3+}$ & 20 & $96.1 \pm 0.3$ \\
\hline
\end{tabular}

Bull. Chem. Soc. Ethiop. 2008, 22(3) 
The effect of various ions on the determination of nickel with MPMP at a fixed concentration of nickel $\left(0.17 \mu \mathrm{g} \mathrm{mL}^{-1}\right)$ and in the presence of different amounts of foreign ions was studied. An error of $\pm 5 \%$ in absorbance was considered tolerable. The results are summarized in Table 1 and indicate that at the given level there is no significant interference with the extraction and spectrophotometric determination of nickel. Thus the system has a high selectivity for nickel ions.

Furthermore, a comparison of analytical parameter obtained by this method and with that reported by several other extraction spectrophotometric methods for determination of nickel is given in Table 2. As could be seen, the presented method has high molar absorptivity and is more sensitive; thus it is suitable for trace analysis of nickel in the sample type examined.

Table 2. Comparison of the present method with other reported spectrophotometric methods.

\begin{tabular}{|c|c|c|c|c|c|c|c|c|}
\hline Reagent & $\mathrm{pH}$ & $\begin{array}{l}\lambda_{\max } \\
(\mathrm{nm})\end{array}$ & $\begin{array}{c}\text { Molar } \\
\text { absorbtivity } \\
\mathrm{M}^{-1} \mathrm{~cm}^{-1}\end{array}$ & M:L & $\begin{array}{c}\text { Linear } \\
\text { range } \\
\left(\mu \mathrm{g} \mathrm{mL}^{-1)}\right.\end{array}$ & $\begin{array}{l}\text { Sandall's } \\
\text { sensitivity } \\
\left(\mu \mathrm{g} \mathrm{cm}^{-2}\right) \\
\end{array}$ & Remarks & Ref. \\
\hline $\begin{array}{l}\text { Thiazole-2-carb- } \\
\text { aldehyde } 2 \text {-quino- } \\
\text { lyl hydrazone }\end{array}$ & $\begin{array}{c}8.7- \\
9.5\end{array}$ & 522 & $7.17 \times 10^{4}$ & $1: 2$ & 0.7 & $8.6 \times 10^{-4}$ & $\begin{array}{l}\text { Poor selectivity } \\
\text { several metal ion } \\
\text { interfere at mole } \\
\text { ratio of greater } \\
\text { than one }\end{array}$ & {$[26]$} \\
\hline $\begin{array}{l}\text { Dimethylgly- } \\
\text { oxime }\end{array}$ & 12 & 470 & & & $0.26-2.1$ & & Poor sensitivity & [27] \\
\hline $\begin{array}{l}\text { N-Ethyl-3-carb- } \\
\text { azolecarbox- } \\
\text { aldehyde-3-thio- } \\
\text { semicarbazone }\end{array}$ & 6.0 & 400 & $1.114 \times 10^{4}$ & $1: 1$ & $1.2-5.6$ & $5.29 \times 10^{-3}$ & $\begin{array}{l}\text { Moderate } \\
\text { sensitivity }\end{array}$ & {$[28]$} \\
\hline $\begin{array}{l}\text { 2-Hydroxy-4-iso- } \\
\text { propoxyaceto- } \\
\text { phenone thio- } \\
\text { semicarbazone }\end{array}$ & 9.0 & 400 & $8.4 \times 10^{2}$ & $\ldots$ & 16.44 & - & $\begin{array}{l}\text { Very poor } \\
\text { sensitivity }\end{array}$ & [29] \\
\hline $\begin{array}{l}\text { 7-Methyl-2-chlo- } \\
\text { roquinoline-3-ca- } \\
\text { rbaldehyde thio- } \\
\text { semicarbazone }\end{array}$ & 6.0 & 410 & $1.67 \times 10^{2}$ & - & 4.0 & - & $\begin{array}{l}\mathrm{Ce}(\mathrm{III}), \mathrm{Al}(\mathrm{III}) \text { and } \\
\mathrm{Ga}(\mathrm{III}) \text { interfered, } \\
\text { very poor } \\
\text { sensitivity }\end{array}$ & {$[30]$} \\
\hline $\begin{array}{l}\text { 2,4-Dihydroxy } \\
\text { acetopheneone } \\
\text { thiosmicarbazone }\end{array}$ & $\begin{array}{l}7.0- \\
8.0\end{array}$ & 385 & $8.2 \times 10^{3}$ & $1: 1$ & $1.0-8.0$ & - & Poor sensitivity & [31] \\
\hline $\begin{array}{l}\text { 2-[(2-mercapto- } \\
\text { phenylimino)- } \\
\text { methyl]phenol }\end{array}$ & $>10$ & 421 & $2.41 \times 10^{5}$ & $1: 2$ & $\begin{array}{c}0.011- \\
0.30\end{array}$ & $5.34 \times 10^{-4}$ & $\begin{array}{l}\text { Sensitive and } \\
\text { selective }\end{array}$ & $\begin{array}{l}\text { This } \\
\text { work }\end{array}$ \\
\hline
\end{tabular}

\section{Application of the proposed method}

To confirm the usefulness of the proposed method, it was applied to the determination of nickel in well water and wastewater samples. For this purpose the samples were first filtered through a Millipore $0.45 \mu \mathrm{m}$ pore-size membrane into previously cleaned polyethylene bottles and were then treated according to the given procedure. Reliability of the method was checked by the spiking experiments and comparing the results with the data obtained by GFAAS. As shown in Table 3, the results obtained with the proposed method agree well with the data obtained by furnace atomic absorption analysis, and the recovery of spiked samples is good, suggesting that the procedure is reliable for the sample type examined.

Furthermore, the above procedure was applied to the determination of nickel in a standard reference alloy C12X3500 (MBH Analytical Limited, U.K.) with composition of $(\mathrm{C}=0.18 \%$, 
$\mathrm{P}=0.029 \%, \mathrm{Cr}=0.31 \%, \mathrm{Co}=0.005 \%, \mathrm{Si}=0.45 \%, \mathrm{Mn}=0.70 \%, \mathrm{Mo}=0.10 \%, \mathrm{Sn}=0.03$ $\%, \mathrm{~W}=0.29 \%, \mathrm{Ti}=0.054 \%, \mathrm{~V}=0.002 \%, \mathrm{Ag}=0.07 \%, \mathrm{~S}=0.032 \%, \mathrm{Ni}=0.18 \%, \mathrm{Cu}=0.15$ $\%$ and $\mathrm{Al}=0.35 \%$ ). The concentration of nickel in the sample was found to be $0.178 \%$ which is in good agreement with the value of $0.18 \%$ reported by MBH Analytical Limited for the above mentioned standard. This further confirmed the reliability of the method for analysis of a wide range of samples.

Table 3. Determination of nickel in well water and waste water samples.

\begin{tabular}{|l|c|c|c|c|}
\hline Sample & $\begin{array}{c}\text { Added } \\
\left(\mu \mathrm{g} \mathrm{L}^{-1}\right)\end{array}$ & $\begin{array}{c}\text { Found }^{\mathrm{a}} \\
\left(\mu \mathrm{g} \mathrm{L}^{-1}\right)\end{array}$ & Recovery $(\%)$ & $\begin{array}{c}\mathrm{GF}^{\mathrm{AAAS}} \\
\left(\mu \mathrm{g} \mathrm{L}^{-1}\right)\end{array}$ \\
\hline Well water & 15.0 & $\begin{array}{c}\mathrm{ND}^{\mathrm{b}} \\
14.8 \pm 0.2\end{array}$ & 98.7 & $5.3 \pm 0.2$ \\
\hline Waste water & 15.0 & $\begin{array}{c}74.2 \pm 0.9 \\
88.7 \pm 1.3\end{array}$ & 96.7 & $73.8 \pm 2.9$ \\
\hline Waste water & 15.0 & $\begin{array}{c}57.3 \pm 1.2 \\
72.2 \pm 1.6\end{array}$ & 99.3 & $57.8 \pm 1.8$ \\
\hline
\end{tabular}

${ }^{\mathrm{a}}$ Mean and standard deviation of three determinations. ${ }^{\mathrm{b}} \mathrm{ND}=$ not detected.

\section{CONCLUSIONS}

In this study for the first time it was shown that the Schiff bases could be used as a ligand for liquid-liquid extraction and spectrometric determination of traces of metal ions. The important features of the method are simplicity, freedom from interferences, high selectivity, with separation ability of MPMP for nickel at trace level. The preconcentration factor of the method is high and it is judged that the procedure have considerable potential for determination of nickel in wastewater samples.

\section{REFERENCES}

1. Merian, E.; Anke, M.; Stoppler, M. Elements and Their Compounds in the Environment, Vol. 2, Wiley, VCH: Weinheim; 2004.

2. Wand, K. Nickel Trace Elements in Life Science, Chinese Measurement Press: Peking; 1991.

3. Zerner, B. Bioorg. Chem.1991, 19, 116.

4. Templeton, D. Biological Monitoring of Chemical Exposure in the Workplace, Word Health Organization: Geneva; 1990.

5. Franson, M.A.H. Standard Methods for Examination of Water and Waste Water, American Publication Health Association; Washington, D.C., USA; 1995.

6. Lin, J.L. J. Chin. Chem. Soc.1986, 33, 215.

7. Yamamoto, Y.; Sugita, M.; Ueda, K. Bull. Chem. Soc. Jpn. 1982, 55, 742.

8. Strelow, F.W.E.; Van der Walt, T.N. Anal. Chim. Acta 1982, 136, 429.

9. Rydberg, J.; Musikas, C.; Choppin, G.R. Principals and Practices of Solvent Extraction, Marcel Dekker: New York; 1992.

10. Tuzen, M.; Melek, E.; Soylak, M. J. Hazard. Mater. 2006, 136, 597.

11. Rump, H.H.; Krist, H. Laboratory Manual for the Examination of Water, Waste Water and Soil, VCH Publisher: New York; 1988.

12. Onishi, H. Photometric Determination of Traces of Metals, Wiley-Interscience: New York; 1984.

13. Marczenko, Z. Separation and Spectrophotometric Determination of Elements, Ellis Harwood: New York; 1986.

14. Alwood, D.A. Coord. Chem. Rev. 1997, 195, 267. 
15. Abd-Elzaher, M.M. J. Chin. Chem. Soc. 2001, 48, 153.

16. Alizadeh, N.; Ershad, S.; Naeimi, H.; Sharghi, H.; Shamsipour, M. Fresenius J. Anal. Chem. 1999, 365, 511.

17. Dadfarnia, S.; Haji Shabani, A.M.; Tamaddon, F.; Rezaei, M. Anal. Chim. Acta 2005, 539, 69.

18. Khorrami, A.R.; Naeimi, H.; Fakhari, A.R. Talanta 2004, 64, 13.

19. Haji Shabani, A.M.; Dadfarnia, S.; Jafari, A.A.; Shahbasi, Z. Can. J. Anal. Sci. Spectros. 2006, 51, 194.

20. Mochizuki, J.; Sonet, T. Anal. Chim. Acta 1996, 319, 387.

21. Sahu, S.K.; Chakravortty, V. J. Radioanal. Nucl. Chem.1988, 227, 163.

22. Lee, C.C.; Syamal, A.; Theriot, L. J. Inorg. Chem. 1971, 10, 1669.

23. Muto, Y. Bull. Chem. Soc. Jap. 1960, 33, 1242.

24. Pazos, C.; Curieses, J.P.S.; Coca, J. Solvent Extr. Ion Exch.1991, 9, 569.

25. Sandell, E.B.; Colorimetric Determination of Trace of Metals, Interscience: New York; 1956.

26. Otomo, M.; Watanabe, T.; Moriya, M. Anal. Sci.1986, $2,549$.

27. Yoshikuni, N.; Baba, T.; Tsunoda, N.; Oguma, K. Talanta 2005, 66, 40.

28. Ramachandraiah, C.; Kumar, J.R.; Reddy, K.J.; Narayana, S.L.; Reddy, A.V. J. Environ. Manage. 2008, 88, 729.

29. Desai, V.K.; Desai, K.K. Orient. J. Chem.1996, 12, 203.

30. Jadhav, V.A.; Kulkarni, M.U. J. Indian Chem. Soc. 1992, 69, 287.

31. Reddy, A.V.; Reddy, Y.K. Talanta 1986, 33, 617. 